\title{
Appreciating the Matters in which the Integrated Reports Respect the IIRC's Requirements: Case Study for the Economic Entities from the European Space
}

\author{
Mariana MAN $^{1}$ and Maria-Mădălina BOGEANU-POPA ${ }^{2}$ \\ ${ }^{1}$ Faculty of Sciences, Department of Economic Sciences, \\ University of Petroșani, Romania \\ ${ }^{2}$ School of Economics, University of Craiova, Romania
}

Correspondence should be addressed to: Maria-Mădălina BOGEANU; madalinabogeanu@yahoo.com

Received date:3 September 2020; Accepted date:5 January 2021; Published date: 5 February 2021

Academic Editor: Daniela Zirra

Copyright (C) 2021. Mariana MAN and Maria-Mădălina BOGEANU-POPA. Distributed under Creative Commons Attribution 4.0 International CC-BY 4.0

\begin{abstract}
This research approaches the international framework regarding the integrated reports the economic entities from the European space develop. Appreciating the measure in which the integrated reports of the European economic entities respect the requirements of the international reporting framework is being referenced. The issued hypotheses within the paper reference to the knowledge and application of the International Integrated Reporting Council's principles. In order to make the study case, an introduction regarding the subject of integrated reporting according to the IIRC's international reporting framework was required. Therefore, it has been established what IIRC is, as well as its objectives, vision, mission and the definition of principles it stands by. The case study is made of a 30 economic entities sample, entities which operate in Europe. Using the content analysis and the method of scoring, it has been studied whether the economic entities make integrated reports while respecting the requirements of the IIRC's international reporting framework. The research's results have proven that applying the IIRC principles is relevant in reflecting the economic entities' performances within the European space and have made possible the validation or invalidation of the initially issued hypotheses. It has been proven through the obtained score that the best IIRC principle implemented within the European space economic entities' reporting is the reporting's credibility.
\end{abstract}

Keywords: integrated reporting, conceptual framework, IIRC principles, economic entity, European area.

Cite this Article as: Mariana MAN and Maria-Mădălina BOGEANU-POPA (2021)," Appreciating the Matters in which the Integrated Reports Respect the IIRC's Requirements: Case Study for the Economic entities from the European Space ", Journal of Eastern Europe Research in Business and Economics Vol. 2021 (2021), Article ID 432176, DOI: 10.5171/2021.432176 


\section{Introduction and motivation}

In the international economic environment, the complexity of the reporting requirements is increasingly higher and aims at the economic entities that develop annual reports by adding the new details and providing an improved degree of expertise (Deloitte, 2012). The economic entities' choice to highlight only the positive aspects, presenting the strengths and omitting the less good aspects, is no longer agreed internationally because it is obvious disadvantages are created from a competitive point of view (Dima, Popa and Farcane, 2015). In the international space, the annual reports drafted by the economic entities have taken various forms, from the simple financial reports to the environmental reports or reports regarding the governance and remuneration of the capital (Păunescu and Man, 2019).

Not only in terms of the name, but also in terms of the content, the integrated reports have undergone also substantial changes over time. Much emphasis has been placed on the interconnection of information and on how to synthesise and present the environmental issues and social responsibility the economic entities were addressing and influenced their performance. The final form of the integrated reporting process is based on an integrated thinking and aims to determine the economic entity to periodically issue an integrated report that has value over time. Currently, the integrated report has a concise form of communicating an entity's strategy, its performances, perspectives, governance and internal and external environment (IIRC, 2013). For this approach, a number of regulatory bodies, investors, economic entities, representatives of the NGOs and professionals practicing the accounting profession has mobilised (Bratu, 2017).
Globally, the international integrated reporting framework of IIRC is the manner of rapid implementation of adopting the integrated reporting. IIRC was constituted

by the interest to internationally adopt the integrated reporting. Organisationally, IIRC presents itself a global coalition consisting of representatives who are members of the council and promotes the interactions with the social and economic environment in order to coordinate and carry out the initiatives and related activities. IIRC is the common interest of the international coalition in the process to implement the integrated reporting. The coalition consists of a wide range of participants involved in integrated reporting, such as: economic entities, capital suppliers, authorities, professionals, regulatory institutions, academic environment or third parties representing the company. IIRC has the status of organisation that operates independently and manages and coordinates centrally matters related to integrated reporting, being an excellent centre of efficient corporative reporting. IIRC is the main manner of interaction with and between its representative members, on the topic of integrated reporting. IIRC has the knowledge, tools and other intellectual properties regarding the integrated reporting, acting in support and for the purpose of economic entities' objectives (IIRC, 2013).

The vision of IIRC refers to how the capital is allocated and to changing the corporate behaviour regarding the objective of financial stability and that of sustainable development through integrated reporting. The mission of IIRC involves the introduction of integrated thinking and integrated reporting practices in each economic entity, regardless of the sector where it operates. The team of the IIRC reporting framework consists of a dedicated personnel and is available in 
providing support, coordination and secretariat regarding the organisation's goals which they are responsible for. Being a model to follow, IIRC applies fundamental concepts which it promotes, so that the council periodically drafts an integrated report (IIRC, 2013).

IIRC takes into account an approach that promotes the communication between the factors involved, taking into account the responsibility and administration of capitals, in order to highlight the interdependencies (Dima, Popa, Farcane, 2015). In the long term, the IIRC vision takes into account the adoption of the principles integrated in all business practices found both in the public sector and private sector, as a way of corporate reporting. All the elements of integrated thinking and reporting work efficiently for the financial stability and sustainability.

Internationally, the reporting framework of IIRC was the topic of discussion for many countries of the world, the purpose of consultations being to set the principles and draw the guidelines by which the integrated report would be outlined. The content of the report is governed by the fundamental concepts, providing many explanations underlying its elaboration. Adapted to the evolution, the reporting framework of IIRC folds on the legal regulations around the world, and the principles issued for the economic entities adopting the integrated reporting must be mobilised in order to accelerate the adaptation process. The reporting framework of IIRC promotes an approach dominated by principles that balance the environment based on flexibility and recognition in a broad context that would allow a high degree of comparability between entities. If an economic entity complies with the requirements of the IIRC reporting framework, but in addition to the information required to be presented through the IIRC, the economic entity also presents additional explanations and information, it is deemed that the entity has drafted an integrated report, as long as the additional information provided does not affect or distort the requirements of the IIRC reporting framework. What the IIRC reporting framework does not provide is related to the specific performance indicators of the Key Performance Indicator Institute (KPI), measuring instruments recognised internationally (KPI, 2018). The personnel responsible to draft the integrated report should take into account a method to measure the appropriate performance, so that it would be appropriate and comprehensive regarding the information provided.

The performance indicators are quantitative indicators used particularly to explain how an economic entity creates value in time and how its capitals are changed. The inclusion of quantitative indicators into the integrated report is recommended and relevant in order to reflect the economic entity's capacity (Păunescu and Man, 2019. The purpose of the integrated report in the vision of the IIRC reporting framework is not represented by determining the monetary value of the economic entity at a given time.

The objectives and concepts underlying the IIRC are based on creating value (in the long, medium and short term), presenting the (social, intellectual, natural, human, manufactured and financial) capital, in other words presenting enough information so it would respond to the needs of interested individuals. Moreover, highlighting the connection between sustainable development and economic value is taken into account, meaning to detail the interconnection between elements, highlighting the performance indicators and creating the context required in the reporting process. In this whole process, the transparency of the information provided is promoted (Bratu, 2017).

The purpose and motivation of this research is to find answers to some questions that arise from the analysis of annual integrated reports published in 2018 by many economic entities in the European area. This research has as reference the framework of the IIRC integrated reporting concept that appeared in December 2013. By the combined use of 
the two methods, the level of compliance of the reports drafted with the requirements of the integrated reporting principles could be determined. In order to measure the quality level of the reports, it is required to compare them with the requirements imposed by the IIRC international reporting framework IIRC (2013). This model is proposed by authors such as Eccles, Krzus and Ribot (2015).

\section{Literature Review}

The conceptual framework of the IIRC is the main support in addressing the financial and non-financial nature, and it defines the integrated reporting as a way of concise communication regarding the strategy, governance, external environment and creation of short, medium and long term value (IIRC, 2013). Through the fact that there is a merging of financial information with the non-financial, the access to information is facilitated for a wide category of users: customers, authorities, community, employees, customers.

Internationally, the social responsibility practices are encouraged, by which the opportunity to apply the sustainable principles is proven (Caraiani et. al., 2015). Moreover, the economic entities are tempted to expose more management elements and less performance ones, which does not conclude the positive influence or good practices, meaning it does not present utility for that economic entity (BonilaPriego, Font and Rosario Pacheco-Olivares, 2014). Meeting the requirements of third parties is an aspect that has been achieved through the publication of non-financial information, but these are included into the entity's strategy. Therefore, we can say that it is desired to exceed the responsibility threshold only by simply presenting the social, environmental and economic aspects (García-Sánchez, Rodríguez-Ariza, Frías-Aceituno, 2013).

Regarding the integrated performance reporting, studies have been drafted, which focused on the factors that influence the integrated reporting (Frías-Aceituno, Rodríguez-Ariza and García-Sánchez, (2013) and Hurghiş (2017)), as well as studies that represented the compliance degree of integrated reports according to the IIRC, being drafted by Eccles, Krzus and Ribot (2015), Dumitrana et al., (2009), Ruiz-Lozano and Tirado-Valencia (2016). By going through these studies, it was found out that the common point is represented by the IIRC conceptual framework. This conceptual framework provides a good reporting base, establishing the guiding principles and elements required to be addressed in an integrated report. Studies such as that drafted by Dumitrana et al., (2009) proposes another model and namely the preparation of a list of factors that refer to the content, and these factors are identified in reports. This method aims to increase the degree of objectivity. Followers of the same method are also authors (RuizLozano and Tirado-Valencia (2016)) who analysed the extent to which industrial companies meet the principles of integrated reporting, and the results of their research prove that not all entities are at the same level of integrated reporting (Kot, Măcriș, 2015).

The definition given to integrated reporting by the international framework of the IIRC is that of a process resulting from an integrated thinking, finalised by a centralised result and transmitted periodically by an economic entity (IIRC, 2013).

Integrated reporting can be deemed the motor of an economic entity in the relation between its functional units and relations it has with third parties. Compared to financial communication, the integrated reporting particularities refer to the value the economic entity creates in the short, medium and long term. Integrated reporting promotes the interdependencies and responds to the needs of third parties, encouraging the connectivity without compromising the economic entity (Man, Bogeanu-Popa, 2020). By adopting the integrated reporting, the economic entity drafts a business and strategy model by which it responds to the requirements of the internal and external environments and takes risks into account. The manner of managing the risks is also presented in the 
integrated report, imposing a separate section where the methods of reducing or combating the risks are presented. The activities of the economic entity governed by integrated reporting follow the financial performance, focusing on capitals. In this process, the information systems are involved which, well incorporated in the economic entity, facilitate the flow of information, coming to support the management to take decisions (BonillaPriego, Font, Pacheco-Olivares, 2014).

By means of the integrated reporting, the principles and concepts designed to bring together increased efficiency and integrated thinking are accepted. The efficiency is reflected by an improved quality of the information sent to third parties, notably an improvement of the relationship with the capital providers. The special attention paid to the latter results in the efficiency and productivity in allocation, which has long-term implications and creates value over time. From a financial perspective, these elements contribute to the stability of global economy.

The integrated report supports the sustainable development strategy and provides a full set of information in an organised and compact manner (Caraiani et. al., 2015). Moreover, a long-term vision is presented regarding the value creation and the interdependence of the aspects presented in the integrated report is emphasised. Being considered one of the most efficient methods by which existing problems are identified, the integrated reporting entails an efficient allocation of the resources within the economic entity and in this way the reporting quality is significantly improved (Hurghiş, 2017). The integrated report is defined through a concise communication of how an economic entity manages its strategy, governance, performance and perspectives, both internally and externally. By drafting the integrated report in compliance with the reporting framework, the objectives, purpose and principles specific to the reporting framework of IIRC are achieved (Păunescu and Man, 2019). The current form of the integrated report mainly addresses the economic players who have private capital, but it can be adapted also to the entities that have public capital or even to non-governmental organisations. By means of the integrated report, a radiography of the economic entity's activity is achieved, by evaluating its capacity to create value over time (Bratu, 2017). Over time, only advantages for all interested parties were identified through the integrated report. According to the IIRC framework, the elaboration of the integrated report can have a stand-alone structure, being distinct from other documents or may be included in the reports made by the economic entity on a regular basis. The usual practice within the economic entities is to include the integrated report in the financial statements drafted. Seen as a means of communication, an integrated report is an introduction to the detailed information available generally in electronic form on the entity's web page so that the access to them is easy for as many people as possible.

Providing an incomplete integrated report that does not meet all the requirements of the reporting framework of IIRC may be justified when the information is unavailable or their disclosure would cause damages to the entity or affect the competition. Justifying the non-representation of the information is a mandatory condition, being required to provide the indications on the nature of omitted data. It is accepted to give explanations on why the information has been omitted or to justify the omission by committing the subsequent completion of the information that was unavailable, specifying the time when it will be published.

In addition to what has been presented, the reporting framework of the IIRC requires that a statement of the legal representative would also exist in the integrated report, which would include the assurance, assumption and recognition of the integrity of the integrated report. In addition to these, a brief description of the people in charge involved in the process of 
integrated reporting and the role played by each is also required. In the elaboration of the integrated report, the information provided should be as generous as possible, compliant with the existing requirements and should meet the framework imposed by the regulatory bodies (Dima, Man, 2015).

The principles specific to the IIRC reporting framework

A number of principles is set out through the conceptual framework of IIRC (2013) in order to achieve a balance between flexibility and regulation. It provides a complete package of key indicators, measuring instruments, requirements and specific information that must be addressed in one form or another by the economic entities in order to align with the IIRC requirements. Professionals have a set of principles at the disposal in order to achieve the integrated report. By applying the principles, an appropriate balance is created between relevance and flexibility, and removes the confusing situations that may arise (Ruiz-Lozano and TiradoValencia, 2016). The IIRC international framework (2013) has formulated the following principles: strategic focus and directing the entity towards the future, the information connectivity, relationships with third parties, importance and relevance, accuracy, credibility, comparability and coherence.

- When we speak of strategic focus and directing the entity towards the future, we refer to a better understanding of the entity's strategy and to how it creates value in the medium and long term. Thus, it will be followed in the reports whether the entity represents the risks and opportunities it has, but also how the goals are set in the future.

- Regarding the connectivity of information, it is intended that within the integrated report, the factors would have interdependence when creating value. It should take into account the content elements between the past, present and future, the presentation of capitals, the presentation of financial information and non-financial information, and not least, the presentation of qualitative and quantitative information.

- Regarding the relations with third parties, the quality of the relationship with third parties is pursued, particularly with the interested parties. A relationship well-built with third parties by how the entity understands and addressed the interests of third parties. The purpose of obtaining the opinion of third parties is often used to document and guide the strategy of the entity and in making the decision and allocating the necessary resources in this direction (Soyka, 2013).

- In terms of the importance and relevance, the aim is to identify the essential issues and how they influence the creation of value. Providing information on the positive and negative aspects, including the risks, opportunities both in terms of financial information and nonfinancial information.

- For the accuracy, it is pursued that the economic entity would not present repetitive information that does not provide relevance. An integrated report drafted by the economic entity has a logical and concise structure, calls for internal and external information, clearly presents the concepts, and does not present general information, but concise and precise information.

- Regarding the credibility, it is required that a report would expose significant information, whether the information is positive or negative, it should be error free.

- The correctness of the information may be rendered by means of the audit or assurance of reports. By a good compliance of the economic entity with this principle, the strategic objectives and competitive advantages are improved, which the entity has.

- The principle of comparability and coherence follows the evolution of the report over time, but a comparison 
can be made between the performances of the economic entities in the same sector of activity. It is important to keep the same performance indicators from one report to another, unless a significant change has occurred within the economic entity.

\section{Methodology Research}

In the research carried out, the content analysis and scoring method were used. The content analysis facilitated the identification and description of objectives in rigorous manner. By this method, the characteristics of the objectives subject to analysis have been identified and counted. The purpose of the content analysis consisted in the initial description of the requirements that should be met, in testing and comparing the content of the reports with the international requirements. An important characteristic of this method refers to formulating the hypotheses regarding the relationships between the concepts analysed. The advantage of using the content analysis refers to the methodical character, more precisely to the objective and quantifiable character. This analysis allows highlighting both the constant elements and those subject to change.

The scoring method is a method based on the discriminating analysis and is often used by those from the economic entity's external environment. The analysis methodology based on scores refers to simultaneously dealing with the multiple characteristics the economic entities have. The method principle is to statistically determine a separation between the economic entities belonging to a group, environment or geographical region. An economic entity's opening towards new horizons of exploitation is the reason why this exploits the opportunities appeared. Affiliation to the European area provides an advantage cultivated in the desire for change. The particularities of each country depend on the national development strategy and on the economic entity's capacity to comply with the highest standards.

In order to achieve an evaluation grid, the requirements of the IIRC international reporting framework (2013) have been analysed, and seven principles of integrated reporting are highlighted:

- P1 - Strategic concentration and orientation of the entity towards the future;

- $\quad$ P2 - Information connectivity;

- $\quad$ P3 - Relationships with third parties;

- P4 - Importance and relevance;

- P5 - Significance;

- P6 - Credibility;

- $\quad$ P7 - Comparability and coherence.

Once the principles are known, in order to carry out this research, two hypotheses have been formulated, which based on the results obtained, will be validated or invalidated:

Hypothesis ( $\left.\mathbf{H}_{\mathbf{0}}\right)$ : Most of the economic entities in the European area emphasise the credibility and significance of the reports when they draft integrated reports.

Hypothesis ( $\left.\mathbf{H}_{1}\right):$ The integrated reports drafted by the economic entities in the European area comply with the requirements of the IIRC International Reporting Framework, depending on the field of activity.

Following the economic entities' analysis, through the principles pursued, it was possible to identify both the strengths and weaknesses, the opportunities and the risks, and for a fairest assessment, it is useful to give coefficients of importance, in order to determine an average score, as a weighted average, following the calculation formula (1):

$$
\overline{\mathrm{I}}=\left(\sum_{x=1}^{n} x i\right) / 2 x
$$


where:

$\overline{\mathrm{I}}=$ average score;

$\mathrm{X}_{1}, \mathrm{X}_{2} \ldots \mathrm{X}_{\mathrm{n}}=$ the principles, with the scores obtained;

$\mathrm{i}=$ constant coefficient.

The scoring method is a method used mainly by investors or creditors to calculate the risk factor that an economic entity has. The method represents a linear combination of a group of significant indicators (principles), each having a statistical base coefficient. The application of the method involves the achievement of two distinct groups, namely the economic entity that meets the principles of the IIRC reporting framework and the economic entity implementing the principles. Thus, for these groups, a linear combination is determined that allows the differentiation of the two groups, by means of the scoring method Z (2):

$$
z=a_{1} x_{1}+a_{2} x_{2}+a_{3} x_{3}+\ldots+a_{n} x_{n}
$$

where:

$\mathrm{z}=$ the score;

$\mathrm{x}=$ the elements involved in the analysis;

$\mathrm{a}=$ weighting coefficients.

where:

$$
\mathrm{m}=\left(\mathrm{x}_{1}+\mathrm{x}_{2}+\ldots+\mathrm{x}_{\mathrm{n}}\right) / \mathrm{n}
$$

$\mathrm{m}=$ average;

$\mathrm{x}_{1}, \mathrm{x}_{2}=$ elements;

$\mathrm{n}=$ the maximum number of analysed.

The validation/invalidation of the hypotheses depended on the results obtained based on the methods applied. The data collected were mainly from the category of reports published periodically by the economic entities concerned. The data collection sources have an official character, being processed further. Data collection involved the use of several techniques and the establishment of various sources, a process specific also to empirical research. The data presented have been enough for the relevance of the results obtained, materialised through tables, conclusions and discussions.

The assessment of the extent to which the integrated reporting complies with the IIRC requirements. Case study for the economic entities in the European area

Adopting the integrated reports internationally in order to reflect the nonfinancial performance of economic entities had considerable impact on the entities, as it is deemed that these aspects have the
The formula for calculating the average (3) was used in order to establish the average scores, so that the average scores obtained by the economic entities were calculated according to the formula:

greatest interest for third parties (Bogeanu-Popa, Man, 2019). This was the reason why this paper addresses the economic entities at European level.

The research analyses the economic entities in the European area that have drafted and published integrated reports. By consulting the international IR Examples Database and through their own websites of the economic entities, a sample of 30 economic entities was obtained, in the reports of which there are or are not references to the IIRC integrated reporting concept. The sample is represented by a number of 30 economic entities from the European area that have reports published for 2018. The aim was to choose a representative economic entity from the European countries that adhered to the integrated reporting standards. When choosing the sample, the random selection technique was used, provided that the economic entity would provide the public with the online environment information. By selecting the sample, it was aimed to cover as many economic sectors as 
Table 1: List of the selected economic entities in the European area

\begin{tabular}{|c|c|c|c|}
\hline No. & Country & $\begin{array}{l}\text { Name of the economic } \\
\text { entity }\end{array}$ & Economic sector \\
\hline 1 & Austria & OMV & Oil and gas \\
\hline 2 & Belgium & Louis Delhaize Group & Retail \\
\hline 3 & Bulgaria & Bulgargaz & Oil and gas \\
\hline 4 & Czech Republic & Skoda & Production \\
\hline 5 & Cyprus & Bank of Cyprus & Banking services \\
\hline 6 & Croatia & Bonbon & Telecommunications \\
\hline 7 & Denmark & Novo Nordisk & Pharmaceutical industry \\
\hline 8 & Estonia & Tallinna farmatsiatehas & Pharmaceutical industry \\
\hline 9 & Finland & Finnair & Aviation \\
\hline 10 & France & Carrefour & Retail \\
\hline 11 & Germany & Continental AG & Production \\
\hline 12 & Greece & Alpha Bank & Banking services \\
\hline 13 & Ireland & Ryanair & Aviation \\
\hline 14 & Island & Actavis & Pharmaceutical industry \\
\hline 15 & Italy & Enel & Energy and resources \\
\hline 16 & Latvia & Latvian airlines & Aviation \\
\hline 17 & Lithuania & Air Lithuanian & Aviation \\
\hline 18 & Luxembourg & RTL Group & Telecommunications \\
\hline 19 & Malta & AirMalta & Aviation \\
\hline 20 & Great Britain & BT Group & Telecommunications \\
\hline 21 & Norway & Aker Solutions & Oil and gas \\
\hline 22 & Holland & KLM Royal Dutch Airlines & Aviation \\
\hline 23 & Poland & PKO Bank Polski & Banking services \\
\hline 24 & Portugal & Coindu & Production \\
\hline 25 & Romania & Banca Transilvania & Banking services \\
\hline 26 & Slovakia & Rova & Production \\
\hline 27 & Slovenia & Adria Airways & Aviation \\
\hline 28 & Spain & Telefonica & Telecommunications \\
\hline 29 & Sweden & Electrolux & Production \\
\hline 30 & Hungary & OTP Bank Group & Banking services \\
\hline
\end{tabular}

Source: The projection of authors based on the data taken from the web pages of the economic entities

For the sampled economic entities that have subsidiaries in several countries, the country of origin of that economic entity was taken into account, and in terms of the annual reports drafted, the consolidated report drafted by the parent entity was taken into account. Based on the constructed sample, Table 2 presents the economic sectors where the researched economic entities operate. 
Table 2: The economic sectors where the selected economic entities operate

\begin{tabular}{|c|c|c|c|}
\hline No. & Economic sector & $\begin{array}{c}\text { Number of economic } \\
\text { entities }\end{array}$ & Share \\
\hline 1 & Banking services & 5 & $16.66 \%$ \\
\hline 2 & Oil and gas & 3 & $10 \%$ \\
\hline 3 & Production & 5 & $16.66 \%$ \\
\hline 4 & Aviation & 7 & $23.34 \%$ \\
\hline 5 & Retail & 2 & $6.66 \%$ \\
\hline 6 & Telecommunications & 4 & $13.34 \%$ \\
\hline 7 & Pharmaceutical industry & 3 & $10 \%$ \\
\hline 8 & Energy and resources & 1 & $3.34 \%$ \\
\hline & Total & 30 & $100 \%$ \\
\hline
\end{tabular}

Source: The projection of authors based on the data taken from the web pages of the economic entities

It is observed that the most representative economic sectors are the aviation with a number of 7 economic entities and a percentage of $23.34 \%$, followed by the sectors of production and banking services, which have a number of 5 economic entities and a percentage of $16.66 \%$ each, and the least representative is the sector of energy and resources with a single economic entity and a percentage of $3.34 \%$. Taking into account the principles of integrated reporting established, the principle P7-Comparability and coherence is a difficult one to evaluate in an objective manner, given that the research has been done only for 2018, the comparability of reports from one period to another not being possible. As a result, this principle was removed from the analysis. Although this principle can be assessed in terms of comparability of the reports of economic entities from the same sector of activity, the score given would not be complete, and the analysis of this principle would be insignificant for this research.

The principles were graded individually starting from 0 to 3 . If the report did not provide information on this element, grade 0 was given, and if the report describes the factor very well, the grade obtained was 3 . Having said this, a report may obtain a maximum score of 18 . In order to increase the degree of objectivity, components were created in order to establish which of these are identified in the content of the reports and intermediary scores have also been given. The intermediary scores were summed and rounded up so that there are no decimals, therefore a score was obtained for each principle. Total scores and average scores were calculated for each economic entity, and average scores for each individual principle. Table 3 details the scores obtained by the economic entities.

Table 3: Total score given for the compliance with the principles specific to integrated

\begin{tabular}{|l|l|l|l|l|l|l|}
\hline $\begin{array}{l}\text { Total score/economic } \\
\text { entity }\end{array}$ & $\mathbf{1 7 - 1 8}$ & $\mathbf{1 5 - 1 6}$ & $\mathbf{1 3 - 1 4}$ & $\mathbf{1 1 - 1 2}$ & $\mathbf{9 - 1 0}$ & $\mathbf{7 - 8}$ \\
\hline $\begin{array}{l}\text { Number of economic } \\
\text { entities }\end{array}$ & 7 & 5 & 6 & 2 & 6 & 4 \\
\hline Percentage & $23.33 \%$ & $16.67 \%$ & $20 \%$ & $6.67 \%$ & $20 \%$ & $13.33 \%$ \\
\hline
\end{tabular}

Source: Authors' projection 
The average score resulting from the analysis of the degree of compliance with the integrated reporting principles is 2.20. Four economic entities are emphasised to have obtained a maximum score, respectively Banca Transilvania (Romania), PKO Bank Polski (Poland), BT Group (Great Britain), OMV (Austria). According to table 3 , it is observed how the score was registered in a percentage of $50 \%$ from 13 14 points upwards, up to the score of 18 points, therefore it is a high score. For the entities in the second half of the classification, legislative issues may be involved to a greater extent than the entity's internal policy. Although not all economic entities have recorded maximum scores, they made considerable efforts to align with the international standards of integrated reporting. Even though the integration level of certain economic entities is lower, the desire to match with the international requirements of the entity must be appreciated and, more than that, one must note the support given by the country of origin of the economic entity in order to apply the European or international regulations regarding the theme of integrated reporting.

The aim of this study is to give scores objectively, the economic entities presenting the most complete and elaborate set of information in reports are rewarded with maximum scores, while the lower scores are obtained by the economic entities presenting in their reports less information or where the absence of information is noticeable.

Figure 1 shows the average scores for each of the principles; it is observed that there is a difference of 0.63 between the maximum and minimum values, which leads to the conclusion that the integrated reports are compliant with the international reporting framework to a great extent.

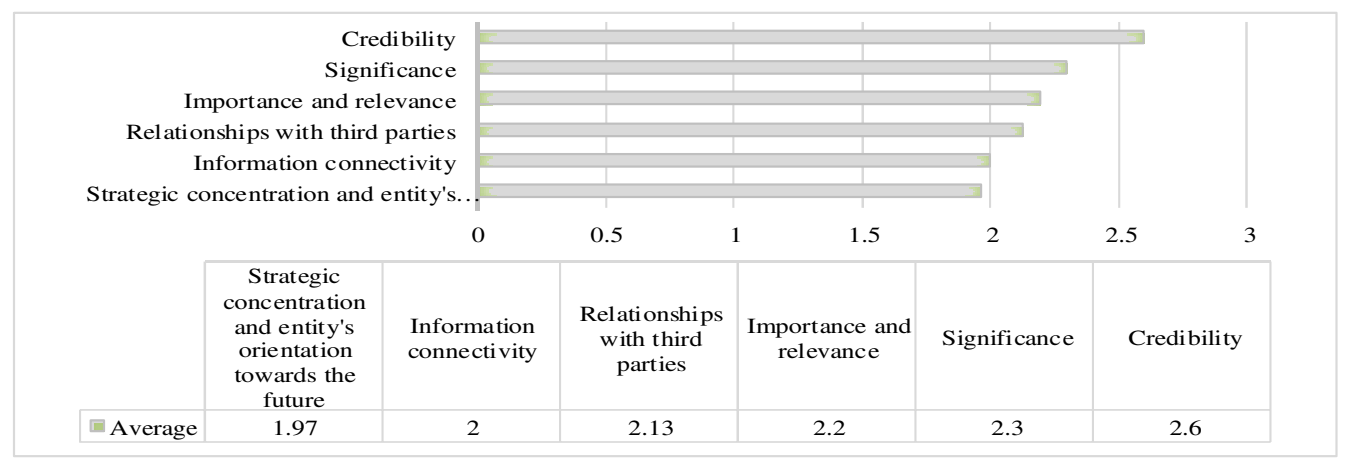

Figure 1: Average scores calculated for the integrated reporting principles Source: Authors' projection based on the IIRC's principles

According to the data obtained from Figure 1 , six of the seven principles will be detailed according to the average scores obtained. The analysis of the principles, together with the average scores obtained by the economic entities will be detailed below.

In the case of the principle P1-Strategic concentration and orientation of the entity towards the future, an average score of 1.97 was obtained. This score is one of the lowest scores obtained, because some of the economic entities did not focus to a large extent on the promoting strategy or on the opportunities the entity has in the future of the activity. Table 4 details the situation of the scores obtained by the economic entities in compliance with the IIRC requirements for this objective. 
Table 4: Scores specific to the principle P1 - Strategic concentration and orientation of the entity towards the future

\begin{tabular}{|c|l|}
\hline Score & \multicolumn{1}{|c|}{ Name of the economic entity } \\
\hline Score 0 & Bulgargaz; Bank of Cyprus \\
\hline Score 1 & Bonbon; Tallinna farmatsiatehas; Finnair; Coindu; Adria Airways; Electrolux. \\
\hline Score 2 & $\begin{array}{l}\text { Louis Delhaize Group; Skoda; Novo Nordisk; Carrefour; Ryanair; Actavis; Enel; } \\
\text { Latvian airlines; Air Lithuanian; RTL Group; AirMalta; Aker Solutions; } \\
\text { Telefonica. }\end{array}$ \\
\hline Score 3 & $\begin{array}{l}\text { OMV; Continental AG; Alpha Bank; BT Group; KLM Royal Dutch Airlines; PKO } \\
\text { Bank Polski; Banca Transilvania; Rova; OTP Bank Group. }\end{array}$ \\
\hline
\end{tabular}

Source: Authors' projection

Following the scores obtained, we can say that the entities studied do not elaborate reports fully compliant with the international integrated reporting framework. Even though most entities obtained scores of 2 and 3 , scores of 0 and 1 were also recorded. The main problem was that in the available reports, no element was found regarding the long-term economic entity's strategy, aspects regarding the allocation of resources in order to achieve the objectives, elements related to capital, respectively the effects produced on capitals and, last but not least, aspects regarding the way in which the entity creates value in the long, medium or short term.

Regarding the principle P2-Information connectivity, score 2 was obtained, a value close to the previous principle, meaning the idea that the entities did not focus very much on this principle, it can be said that its level is an acceptable one. Table 5 details the scores obtained by the economic entities in order to find out the degree of compliance with the international standards for integrated reporting.

Table 5: Scores specific to the principle - P2 Information connectivity

\begin{tabular}{|c|l|}
\hline Score & \multicolumn{1}{|c|}{ Name of the economic entity } \\
\hline Score 0 & Bank of Cyprus; Rova. \\
\hline Score 1 & $\begin{array}{l}\text { Louis Delhaize Group; Bulgargaz; Tallinna farmatsiatehas; Finnair; Actavis; } \\
\text { Adria Airways; Coindu. }\end{array}$ \\
\hline Score 2 & $\begin{array}{l}\text { Skoda; Bonbon, Continental AG; Ryanair; Enel; Latvian airlines; Air Lithuanian; } \\
\text { Aker Solutions; Telefonica; Electrolux }\end{array}$ \\
\hline Score 3 & $\begin{array}{l}\text { OMV; Novo Nordisk; RTL Group; AirMalta; BT Group; KLM Royal Dutch Airlines; } \\
\text { PKO Bank Polski; Banca Transilvania; OTP Bank Group; Carrefour; Alpha Bank. }\end{array}$ \\
\hline
\end{tabular}

Source: Authors' projection

From the table presented, we can see that most of the economic entities have good scores, meaning of 2 and 3, which proves that they either achieved a connection in terms of the capitals and business model, or focused on qualitative information and qualitative indicators. The entities that received low scores, between 0 and 1 , had problems regarding the non-correlation of the presentation of financial information with the non-financial information or deficiencies in the non-correlation of the resources allocated in the entity's strategy. All these lead to reducing the connectivity effect and affect the process of alignment with the standards imposed by the international reporting framework.

In connection with the principle P3-The principle of relationships with third parties, the entities analysed registered a good score of 2.13. It results that a set of 
information has been presented on third parties, particularly on the parties interested in the economic entity; all except for one economic entity that scored 0 on this principle, according to Table 6 .

Table 6: Scores specific to the principle P3-Relationships with third parties

\begin{tabular}{|c|l|}
\hline Score & \multicolumn{1}{|c|}{ Name of the economic entity } \\
\hline Score 0 & Coindu. \\
\hline Score 1 & Tallinna farmatsiatehas; Finnair; Actavis; Adria Airways. \\
\hline Score 2 & $\begin{array}{l}\text { Louis Delhaize Group; Bulgargaz; Bank of Ciprus; Bonbon; Alpha Bank; } \\
\text { Ryanair; Latvian airlines; Air Lithuanian; AirMalta; Aker Solutions; Rova; } \\
\text { Telefonica; Electrolux. }\end{array}$ \\
\hline Score 3 & $\begin{array}{l}\text { OMV; Skoda; Novo Nordisk; Carrefour; Continental AG; RTL Group; BT Group; } \\
\text { KLM Royal Dutch Airlines; PKO Bank Polski; Banca Transilvania; OTP Bank } \\
\text { Group. }\end{array}$ \\
\hline
\end{tabular}

Source: Authors' projection

By means of the P3 principle, the relationships that the entities have with the interested parties were mainly aimed at, but also the extent to which the entity takes into account their opinion and wants to meet their expectations. This is highly important because the group of users of this type of information largely consists of capital providers. Also, the international integrated reporting framework encourages the provision of as much information as possible to capital providers, as they are an important category of information users (Soyka, 2013).
Regarding the principle P4-Importance and relevance, the scores obtained by entities are high, the average score being 2.20. The analysis of this principle took into account the identification of significant elements regarding the important aspects in the process of operating the entity's activity. Table 7 details the status of the scores obtained by each individual entity, reflecting the degree of compliance with the international integrated reporting requirements.

Table 7: Scores specific to the principle P4-Importance and relevance

\begin{tabular}{|c|l|}
\hline Score & \multicolumn{1}{|c|}{ Name of the economic entity } \\
\hline Score 1 & Tallinna farmatsiatehas; Finnair; Actavis; Coindu; Adria Airways; Electrolux \\
\hline Score 2 & $\begin{array}{l}\text { Bulgargaz; Bonbon; Bank of Ciprus; Alpha Bank; Ryanair; Enel; Latvian } \\
\text { airlines; Air Lithuanian; RTL Group; Aker Solutions; Rova; Telefonica; OTP } \\
\text { Bank Group. }\end{array}$ \\
\hline Score 3 & $\begin{array}{l}\text { OMV; Louis Delhaize Group; Skoda; Novo Nordisk; Carrefour; Continental AG; } \\
\text { AirMalta; BT Group; KLM Royal Dutch Airlines; PKO Bank Polski; Banca } \\
\text { Transilvania; OTP Bank Group. }\end{array}$ \\
\hline
\end{tabular}

Source: Authors' projection

Following the analysis, descriptions of the activity were found in all reports, which led to a score of at least 1 , for providing minimal information. However, most economic entities provided significant, relevant and important information regarding their activity. Significant, welldetailed and well-argued matrices of significance were noted in the reports, and this indicates that the aspects on the international integrated reporting policies have been complied with. Moreover, the presentation of the significant risks, of the method to combat the risks or mitigate them, is an aspect of major importance in an economic entity. On this topic, authors 
such as Eccles, Krzus and Ribot (2015) believe that an entity can identify the main risks better than to explain them.

Regarding the principle P5-Significance, it obtained almost the highest average score, meaning 2.3. This score is reflected in the effort made by economic entities to repeat the information presented, and what the entities develop consists of logical and concise information that follows a welldefined and coherent structure. According to Table 8 , most entities obtained scores between 2 and 3 .

\section{Table 8: Scores specific to the principle P5-Significance}

\begin{tabular}{|c|l|}
\hline Score & \multicolumn{1}{|c|}{ Name of the economic entity } \\
\hline Score 1 & Bonbon; Alpha Bank; Telefonica; Air Lithuanian; Rova. \\
\hline Score 2 & $\begin{array}{l}\text { Bulgargaz; Novo Nordisk; Tallinna farmatsiatehas; Carrefour; Ryanair; Enel; } \\
\text { Latvian airlines; AirMalta; Aker Solutions; Bank of Ciprus; Coindu; Electrolux; } \\
\text { Finnair; Actavis; Adria Airways. }\end{array}$ \\
\hline Score 3 & $\begin{array}{l}\text { OMV; Louis Delhaize Group; Skoda; Continental AG; RTL Group; BT Group; } \\
\text { KLM Royal Dutch Airlines; PKO Bank Polski; Banca Transilvania; Telefonica; } \\
\text { OTP Bank Group. }\end{array}$ \\
\hline
\end{tabular}

Source: Authors' projection

The failure to give the maximum score to this principle was due to repetitive information, meaning the presentation of the same information in several sections of the report. Although authors such as Eccles et al. (2012) consider that the integrated reports have a narrative character, according to the international reporting frameworks, they must be precise and concise.
The principle $\boldsymbol{P 6}$ - Credibility obtained the highest average score, respectively 2.6. As a result, it can be concluded that the economic entities have presented information where a clear, credible and coherent picture of the annual reports drafted results from, which are also in line with the international reporting framework, with no errors in this process. These data are detailed in Table 9.

Table 9: Scores specific to the principle P6-Credibility

\begin{tabular}{|c|l|}
\hline Score & \multicolumn{1}{|c|}{ Name of the economic entity } \\
\hline Score 1 & Rova. \\
\hline Score 2 & $\begin{array}{l}\text { Bulgargaz; Louis Delhaize Group; Bank of Ciprus; Bonbon; Finnair; Air } \\
\text { Lithuanian; Aker Solutions; Coindu; Adria Airways; Electrolux. }\end{array}$ \\
\hline Score 3 & OMV; Novo Nordisk; Skoda; Continental AG; Enel; Latvian airlines; RTL Group; \\
& $\begin{array}{l}\text { BT Group; KLM Royal Dutch Airlines; PKO Bank Polski; Tallinna } \\
\text { farmatsiatehas; Carrefour; Alpha Bank; Ryanair; Actavis; AirMalta; Banca } \\
\text { Transilvania; Telefonica; OTP Bank Group. }\end{array}$ \\
\hline
\end{tabular}

Source: Authors' projection

For more credibility in this regard, part of the economic entities confirmed and validated the information through the audit, which also brought assurance on the accuracy of the information provided (IIRC, 2013). Moreover, external opinions have been formulated regarding the elaborated reports, which is a key element of the international integrated reporting policies (Man, Bogeanu-Popa, 2020).

\section{Discussions and conclusions}

In this paper, the research represents the direct reflection of the reality. Two research methods were used, respectively qualitative and quantitative research. Through the qualitative research, we could collect and analyse data not represented by numbers, the former being of exploitation and understanding character. The 
processes are described without interfering with them and important characteristics of a subject are emphasised. In the qualitative research, description was used to detail and describe the characteristics and to highlight the existing links. Through quantitative research, we could collect and process the data and the results of processing the data could be emphasised.

We observe that the economic entities in the European area that have complied exactly with the requirements or those that have come as close as possible to them have recorded high scores for each of the principles analysed. They provided wellstructured, logical, detailed reports, which presented the value created and promoted the business model. By comparison, the entities that obtained lower scores need to make additional efforts to draft integrated reports. It can be said that the economic entities in this situation are entities in an early stage of integrated reporting. Having said this, we can establish the validation or invalidation of the hypotheses.

In the case of hypothesis $\left(\mathrm{H}_{0}\right)$, this is validated because most of the companies in the European area emphasise the credibility and significance of reports, when they draft integrated reports, which is proven by the highest averages scores obtained. In the case of significance, the score of 2.3 was obtained and in the case of credibility, the score of 2.6 was obtained. This is reflected in Figure 1. Average scores for the principles of integrated reporting, in Table 8. Scores specific to the principle P5Significance and Table 9. Scores specific to the principle P6-Credibility.

In the case of hypothesis $\left(H_{1}\right)$, this is not validated. The invalidation of this hypothesis is justified by the fact that the economic entities in the European area do not draft integrated reports in compliance with the requirements of the International Reporting Framework of the IIRC depending on the field of activity. In this case study, there is a relatively homogeneous distribution of business sectors and the scores obtained by the entities are varied and differ depending on the principles they comply with. This is confirmed by Table 1 . The economic sectors in which the economic entities operate and reflected in Figure 1. Average scores for the integrated reporting principles.

The limits of this research refer to the relatively low number of economic entities, but representative for the European states that have adopted the principles of integrated reporting according to international requirements. The limitation of the study is given by the fact that a report was made for Europe, and not for several continents. Another limitation of this research refers to how the scores are given, because it can be a subjective one and influences the results. In order to overcome the limitations of this case study, the research can be extended to several continents and for a longer period of time, which would allow the possibility of a better comparison, spread over several years. The advantage offered would be to observe the evolution of the reports drafted from one year to another or from the first reference year to the last reference year.

In conclusion, this research refers to integrated reports specific to economic entities in the European area on the compliance with the international principles of integrated reporting (IIRC, 2013). The research sample analysed consisted of 30 economic entities from the European area, being analysed for each integrated reporting. For the research, methods were used by which the extent to which the principles were complied with were aimed at. By means of the study carried out, the general conclusion is that the economic entities in the European area are in different stages of compliance with the requirements imposed by the IIRC.

\section{Acknowledgment}

"This paper was supported by the grant P0CU380/6/13/123990, co-financed by the European Social Fund within the Sectorial Operational Program Human Capital 2014 - 2020." 


\section{References}

- Bogeanu-Popa, M.M., and Man, M., (2019). Considerations Regarding the Way of Management of the Environmental Accounting within the Organization's Economic System. Proceedings of the 33rd International Business Information Management Association (IBIMA), ISBN: 978-0 9998551-2-6, 10-11 April 2019, Granada, Spain.

- Bonilla-Priego, M.J., Font, X. and Pacheco-Olivares,

M.D.R., (2014). Corporate sustainability reporting index and baseline data for the cruise industry. Tourism Management, vol. 44, 149 - 160.

- Bratu, A., (2017). Empricial study regarding the integrated reporting practices in Europe. Audit Financiar, vol. XV, (4), 613-627.

- Caraiani, C., Lungu, C., Dascălu. C. and Colceag, F., (2015). Green Accounting Initiatives and Strategies for Sustainable Development, IGI Global Publishing House, USA.

- Dima, I.C. and Man, M., (2015). Modelling and Simulation in Management - Econometric Models Used in the Management of Organizations, Springer International Publishing, Switzerland.

- Dima, S., Popa, A. and Farcane, N., (2015). Financial and Non-Financial Information in the Framework of Sustainability and Integrated Reporting. Audit financiar, vol. XIII, (2), 21-33.

- Dumitrana, M., Jianu, I., Lapteş, R. and Popa, A.F., (2009). Sustainable development and

- environmental accounting: concepts, trends and quality of accounting information. Journal of Accounting and Management Information Systems, vol. 8, (1), 27-39.

- Eccles, R.G., Krzus, M.P. and Watson, L.A., (2012). Integrated Reporting Requires Integrated Assurance în Effective Auditing for Corporates: Key Developments in Practice and Procedures, Bloomsbury Information Ltd London.
- Eccles, R.G., Krzus, M.P, and Ribot, S., (2015). The Integrated Reporting movement. Hoboken, New Jersey: John Wiley \& Sons Inc.

- Frías-Aceituno, J., Rodríguez-Ariza, L., and García-Sánchez, I.M., (2013). Is integrated reporting determined by a country's legal system? An exploratory study. Journal of Cleaner Production, vol. 44, 45-55.

- García-Sánchez, I., Rodríguez-Ariza, L. and Frías-Aceituno, J., (2013). The cultural system and integrated reporting. International Business Review, vol. 22, (5), 828-838.

- Hurghis, R., (2017). Integrated reporting and Board features. Audit Financiar, vol. XV, (1), 83-92.

- Kot, S., and Măcriș, M., (2015). Companies'Operation Environments in a Global Economy in Systemic Approaches to Strategic Management; Dima, I.C. et al. (eds.), IGI Global Publishing House, USA, 50-63.

- Man, M. and Bogeanu-Popa, M.-M., (2020). Impact of Non-Financial Information on Sustainable Reporting of Organisations' Performance: Case Study on the Companies Listed on the Bucharest Stock Exchange. Sustainability, vol. 12 (6), 2179. DOI https://doi.org/10.3390/su12062179.

- Păunescu, C.F., and Man, M., (2019). Aspects regarding the Binomial Social Accounting-Social Performance within Social Responsibility of Romanian Organizations. In Proceedings of the 34th International Business Information Management Conference (34th IBIMA), Madrid, Spain, 13-14 November 2019.

- Ruiz-Lozano, M. and Tirado-Valencia, P., (2016). Do industrial companies respond to the guiding principles of the Integrated Reporting framework? A preliminary study on the first companies joined to the initiative. Spanish Accounting Review, vol. 19, (2), 252-260.

- Deloitte, (2012). Integrated Reporting. Navigating your way to a truly Integrated Report. [online] Available at: <https://www.iasplus.com/en/publicat ions/southafrica/othe r/integratedreportingissue3/at downlo 
ad/file/ZA\%20Integrated\%20Reportin g\%20Aug\%202012.pdf> [Accessed 01 December 2019].

- IR Examples Database. Integated Reporting Examples database. Available online: $\quad \underline{\text { http://examples.integrat }}$ edreporting.org/home [Accessed 06 December 2019].

- Soyka, P., (2013). The International Integrated Reporting Council (IIRC) Integrated Reporting Framework: Toward better sustainability reporting and (way) beyond, Environmental Quality. [online] Available at:<http://greenleadersdc.com/wpcontent/upload s/2014/11/TowardBetter-Sustainability-Reporting-andBeyond.pdf> [Accessed 18 December 2019].
- Sustainable Development Knowledge Platform (2019). Voluntary National ReviewsDatabase, [online] Available at: https://sustainabledevelopment.un.org Lvnrs/ [Accessed 11 May 2020].

- The International Integrated Reporting Council (IIRC), 2013b. The International $<I R>$ Framework. [online] Available at: $<$ http://integratedreporting.org/wpcon tent/uploads/2013/12/13-1208THEINTERNATION AL-IRFRAMEWORK-2-1.pdf $>$ [Accessed 01 November 2019].

- $\quad$ The KPI Institute (KPI), 2018. Practice domains. [online] Available at: <https://kpiinstitute.org/consulting/pr actice-domains/> [Accessed 17 November 2019]. 